\title{
Juventude Batista Brasileira: a mobilização e o preparo de líderes de ministérios de juventudes batistas
}

\author{
Orientador: Abimar Oliveira de Moraes \\ Mestrando: Jorge Vinicius Vargas Machado \\ Área de Concentração: Teologia Sistemático-Pastoral \\ Linha de Pesquisa: Fé e Cultura
}

As juventudes têm sido influenciada por culturas alinhadas ao espírito desse tempo e que nada tem a ver com os valores cristãos. Num tempo em que o mundo passa por transformações em muitos aspectos, está em curso a transição para uma nova configuração de comportamentos humanos. Por ainda ser fase inacabada, não se pode ter uma leitura correta de como as coisas serão. É possível, no entanto, perceber como os jovens encaravam a vida no passado recente e como a vida tem sido encarada no mundo líquido moderno. Na impossibilidade de definir como é a juventude atual, ao menos as tendências de comportamento podem ser percebidas. Esse cenário, novo e desafiador, é o campo de atuação dos ministérios de juventudes das igrejas batistas. Através de levantamento bibliográfico de livros, pesquisas oficiais, artigos acadêmicos, dissertações e teses defendidas, esta pesquisa pretende descrever quem são as juventudes modernas, quais as culturas e as tendências que influenciam essas juventudes, e as maneiras de lidar com elas sob uma perspectiva pastoral cristã, particularmente batista. Levando em conta o que já foi feito e o que está em andamento de maneira oficial na denominação batista no Brasil, para que se possa apontar onde queremos chegar enquanto jovens batistas brasileiros.

Palavras-chave: Juventudes. Ministério. 